\title{
Strong association of the tissue inhibitor of metalloproteinase-2 polymorphism with an increased risk of oral squamous cell carcinoma in Europeans
}

\author{
ELEFTHERIOS VAIRAKTARIS ${ }^{1}$, CHRISTOS YAPIJAKIS ${ }^{1}$, ATHANASIOS YIANNOPOULOS ${ }^{2}$, \\ STAVROS VASSILIOU $^{1}$, ZOE SEREFOGLOU ${ }^{1}$, ANTONIS VYLLIOTIS ${ }^{1}$, EMEKA NKENKE ${ }^{3}$, \\ SPYRIDOULA DERKA ${ }^{1}$, ELENA CRITSELIS ${ }^{1}$, DIMITRIOS AVGOUSTIDIS ${ }^{1}$, \\ FRIEDRICH W. NEUKAM ${ }^{3}$ and EFSTRATIOS PATSOURIS ${ }^{4}$
}

\begin{abstract}
${ }^{1}$ Department of Oral and Maxillofacial Surgery, University of Athens Medical School, Vas. Sofias 93 and Dim. Soutsou 1; Departments of ${ }^{2} 1$ st Surgical Clinic, ${ }^{3}$ Pathology, University of Athens Medical School, Mikras Asias 75, 11521 Athens, Greece; ${ }^{4}$ Department of Oral and Maxillofacial Surgery, Universität Erlangen, Klinik und Poliklinik für Mund-, Kiefer-, Gesischtschirurgie, Glueckstrasse 11, Erlangen D-91054, Nürnberg, Germany
\end{abstract}

Received November 10, 2006; Accepted December 28, 2006

\begin{abstract}
The present study was performed in order to investigate the possible association of the $-418 \mathrm{G} / \mathrm{C}$ polymorphism in the tissue inhibitor of metalloproteinase-2 (TIMP-2) gene, which affects its expression, with the risk of developing oral cancer. PCR-based restriction analysis was performed in DNA samples from 158 patients with oral squamous cell carcinoma (OSCC) and 168 healthy controls of equivalent sex, age and ethnicity (Greeks and Germans). Statistical analyses were performed with Fisher's exact test and the calculation of odds ratios with a $95 \%$ confidence interval (CI). The frequency of the low $\mathrm{C}$ allele expression was ten times greater in the patients than the controls $(31 \%$ vs $2.7 \%$, respectively; $\mathrm{P}<0.001$ ). The $\mathrm{C} / \mathrm{C}$ and $\mathrm{G} / \mathrm{C}$ genotypes were associated with an increased risk of developing OSCC $(\mathrm{P}<0.001, \mathrm{OR}=40.88,95 \% \mathrm{CI}=2.24-744.40$, and $\mathrm{P}<0.001$, $\mathrm{OR}=21.31,95 \%=9.82-46.21$, respectively). The same pattern of significant differences with the controls was also observed in the subgroups of patients in regard to the initial or advanced stages of oral cancer, family history of any type of cancer or thrombosis, and smoking habits or alcohol abuse. These findings are consistent with the reduced levels of TIMP-2 in
\end{abstract}

Correspondence to: Professor Eleftherios Vairaktaris, Department of Maxillofacial Surgery, University of Athens Medical School, Vas. Sofias 93 and Dim. Soutsou 1, 11521 Athens, Greece

E-mail: lvairakt@med.uoa.gr

Key words: tissue inhibitor of metalloproteinase-2, polymorphism, Caucasians, oral squamous cell carcinoma, oral cancer the presence of the low expression $\mathrm{C}$ allele, which are insufficient to inhibit the matrix metalloproteinase-driven degradation of the extracellular matrix (leading to cancer invasion) and mitogen-driven neoangiogenesis (leading to tumor growth and metastasis). In conclusion, the studied TIMP-2 polymorphism is strongly associated with an increased risk of OSCC in Europeans carrying the low C allele expression. These results indicate that this polymorphism could serve as a genetic marker for the susceptibility of cancer in the oral cavity.

\section{Introduction}

Oral squamous cell carcinoma (OSCC) is the sixth most common malignancy and a major cause of cancer morbidity and mortality worldwide, with more than 300,000 new cases being diagnosed annually all over the world $(1,2)$. This malignancy arises as a result of a multistep process in which several factors, such as environmental agents (smoking, alcohol, dietary habits and certain viruses) and genetic events (alterations in oncogenes and tumor suppressor genes) play an accumulating role (3). Recently, common inherited polymorphisms that are related to inflammation, angiogenesis and thrombosis have also been correlated with an increased risk of malignant tumors developing and progressing in the oral cavity (4-9). Such a factor, which is known to play an important role in angiogenesis and in the progression of OSCC, is the tissue inhibitor of metalloproteinase 2 (TIMP-2) (10-12).

TIMP-2 is a natural inhibitor of matrix metalloproteinase (MMP)-2, a member of a family of proteases involved in the degradation of the extracellular matrix (10). Moreover, TIMP-2 has a unique role in its ability to directly suppress the proliferation of endothelial cells in vitro and angiogenesis in vivo independently of the MMP-2 inhibition $(10,11)$. In 
addition, TIMP-2 is implicated in cell growth and apoptosis $(13,14)$. Taking all these characteristics into account, several recent studies have reported a relationship between the increased TIMP-2 expression and the progression of certain malignancies including OSCC, serous ovarian carcinomas and urothelial bladder carcinomas (12,14-16).

A single nucleotide $\mathrm{G} / \mathrm{C}$ polymorphism has been identified at position -418 in the promoter region of the TIMP-2 gene $(17,18)$. The presence of the $G$ allele has been shown to be associated with increased gene expression, possibly because it favours the binding of the Sp1 transcription factor on a consensus sequence in the promoter region of the TIMP-2 gene $(19,20)$. The frequency of the $\mathrm{C}$ allele ranges between $10-20 \%$ in East Asians while in Caucasians it is considered to be much rarer. $(18,20-24)$.

This polymorphism has been studied in Thai patients with head and neck squamous cell carcinoma. However, the results were inconclusive (20). Therefore, we investigated the possible association of the TIMP-2 -418 G/C gene polymorphism with an increased risk of oral cancer in European patients in comparison to healthy controls.

\section{Materials and methods}

The individuals under study were 326 Greeks and Germans, who participated after informed consent. The Departments of Oral and Maxillofacial Surgery of the Universities of Athens and Erlangen considered all the ethical aspects of this study and approved the protocol used. The studied individuals included 158 patients with oral squamous cell carcinoma and 168 healthy blood donors of equivalent ethnicity, age and gender. The age of the patients ranged between $40-80$ years (mean age 58.6 \pm 10.2 years) and the age of the controls varied between $38-83$ years (mean age $54.7 \pm 11.9$ years). The studied individuals were mostly men: $79.7 \%$ of the patients $(\mathrm{N}=126)$ and $75 \%$ of the controls $(\mathrm{N}=126)$.

The patients included in this study had already developed oral cancer and had received surgical treatment within the last decade. In addition to a clinical presentation, a biopsy with a pathological diagnosis of tumor stages I-IV and a family history regarding any type of cancer or thrombosis, were available for each patient. Fifty eight patients $(36.7 \%)$ had one or two first-degree relatives with cancer and their age range of $41-83$ years $(58.6 \pm 10.4$ years $)$ did not differ significantly from the whole group of patients. Furthermore, thirty two patients $(20.3 \%)$ had one or two first-degree relatives with idiopathic thrombosis and an age range of 44-75 years $(58 \pm 9.9)$, again with no statistical difference when compared to the whole group. Sixteen patients $(10.1 \%)$ had a positive family history for both cancer and thrombosis with a mean age of $56.3 \pm 8$ years. Nearly all the patients $(93.7 \%)$ were smokers and about a third of them were alcohol abusers $(32.9 \%)$. Most of the studied individuals worked in a lowrisk environment (with the exception of one patient and three controls who worked in chemical factories).

Blood samples were collected from all the individuals under study and DNA was isolated with the use of the Nucleon $^{\text {TM }}$ kit (Amersham). Molecular detection of the -418 G/C polymorphism in the TIMP-2 gene was performed by restriction fragment length polymorphism typing. This involved a combination of PCR amplification and digestion with restriction endonuclease $\mathrm{Hgal}$ followed by gel electrophoretic analysis. The PCR conditions consisted of an initial denaturation step at $95^{\circ} \mathrm{C}$ for $5 \mathrm{~min}$, followed by 35 cycles of $94^{\circ} \mathrm{C}$ for $55 \mathrm{sec}, 55^{\circ} \mathrm{C}$ for $1 \mathrm{~min}$, and $72^{\circ} \mathrm{C}$ for $55 \mathrm{sec}$, as well as a final elongation step at $72^{\circ} \mathrm{C}$ for $7 \mathrm{~min}$. The primers used were sense: 5'- GGATCCTGTCAGTTTCTCAA-3' and antisense: 5'- TTTCCCCTTCAGCTCGACTCT-3'. The generated PCR product of $176 \mathrm{bp}$ was cleaved by the restriction enzyme, Hgal, into two fragments of 109 and 67 bp when the $\mathrm{C}$ allele was present, and while the $\mathrm{G}$ allele was not digested. For the verification of the molecular typing results, some of the samples were tested twice and their genotype was also confirmed by DNA sequencing.

The statistical analyses were performed using $\mathrm{SAS}^{\circledR}$ software (version 9.0; SAS Institute Inc.). The genotype distribution and allelic frequencies were analyzed with Fisher's exact test using the exact table P-values. The genotype frequencies of the whole group or subgroups of patients were compared to the respective genotypes of the control group. In all the statistical analyses, it was assumed that there were no patients in the control group with a family history of cancer, or thrombosis, nicotine or alcohol abuse. Thus, odds ratios are most likely expected to overestimate the true likelihood of the TIMP-2 genotypes and these variables. The age criterion for the adjustment of odds ratios has been set at 60 years. Similar frequency distributions regarding age are found in the respective genotypes between the controls and patients. The Mantel-Haenszel method was used for the calculation of all odds ratios with a $95 \%$ confidence interval (CI). A P-value $<0.05$ was considered statistically significant. All the observed genotype and allele frequencies were analyzed according to Hardy-Weinberg, in order to avoid the possibility of potential bias.

\section{Results}

The obtained data of the detected TIMP-2 genotypes in the healthy controls and patients with OSCC are shown in Tables I-IV. The two studied European populations (Greeks and Germans) displayed no significant differences in the genotype and allele frequencies of the $-418 \mathrm{G} / \mathrm{C}$ polymorphism, either among the controls or the patients (Table I). Therefore, the data for the two populations under study were analyzed together (Tables II-IV). All the observed genotype and allele frequencies did not decline from the Hardy-Weinberg equilibrium.

A highly significant difference in the G/C heterozygotes was observed between the oral cancer patients and the controls $(54.4 \%$ vs $5.4 \%$, respectively, $\mathrm{OR}=21.31,95 \%$ $\mathrm{CI}=9.82-46.21, \mathrm{P}<0.001)$. In comparison to the controls, who had a very low $\mathrm{C}$ allele frequency $(2.7 \%)$ in accordance to previously studied Caucasian populations, the patients had a $\mathrm{C}$ allele frequency which was about ten times higher $(31 \%$, $\mathrm{P}<0.001)$.

This pattern of highly significant differences in the $\mathrm{C}$ allele and carrier frequencies in comparison to the controls was observed in all the subgroups of patients in regard to i) early or advanced cancer stages, ii) with or without positive family history of cancer, iii) with or without positive family 
Table I. Prevalence of the TIMP-2 (-418G/C) polymorphism in the patients and healthy controls of Greek and German origin.

\begin{tabular}{|c|c|c|c|c|c|c|}
\hline & \multicolumn{3}{|c|}{ Controls } & \multicolumn{3}{|c|}{ Patients } \\
\hline & Total & Greeks & Germans & Total & Greeks & Germans \\
\hline \multicolumn{7}{|l|}{ Genotypes } \\
\hline $\mathrm{C} / \mathrm{C}$ & $0(0 \%)$ & $0(0 \%)$ & $0(0 \%)$ & $6(3.8 \%)$ & $5(4.8 \%)$ & $1(1.9 \%)$ \\
\hline $\mathrm{G} / \mathrm{G}$ & $159(94.6 \%)$ & $107(95.5 \%)$ & $52(92.9 \%)$ & $66(41.8 \%)$ & $40(38.5 \%)$ & $26(48.1 \%)$ \\
\hline $\mathrm{G} / \mathrm{C}$ & $9(5.4 \%)$ & $5(4.5 \%)$ & $4(7.1 \%)$ & $86(54.4 \%)$ & $59(56.7 \%)$ & $27(50 \%)$ \\
\hline Total & 168 & 112 & 56 & 158 & 104 & 54 \\
\hline \multicolumn{7}{|l|}{ Prevalence of $\mathrm{T}$ allele } \\
\hline $\mathrm{C}$ allele freqency & $9 / 336(2.7 \%)$ & $5 / 224(2.2 \%)$ & $4 / 112(3.6 \%)$ & $98 / 316(31 \%)$ & $69 / 208(33.2 \%)$ & $29 / 108(26.9 \%)$ \\
\hline $\begin{array}{l}\text { Carrier frequency } \\
\text { of } \mathrm{C} \text { allele }\end{array}$ & $9 / 168(5.4 \%)$ & $5 / 112(4.5 \%)$ & $4 / 56(7.1 \%)$ & $92 / 158(58.2 \%)$ & $64 / 104(61.5 \%)$ & $28 / 54(51.9 \%)$ \\
\hline
\end{tabular}

The frequencies of the genotypes and C alleles are not significantly different among the two studied populations, either among the controls or the patients. TIMP-2, tissue inhibitor of metalloproteinase-2.

Table II. Prevalence of the TIMP-2 (-418G/C) polymorphism in the healthy controls and the total group of patients and their subgroups, in regard to the oral cancer stage.

\begin{tabular}{|c|c|c|c|c|c|c|c|c|c|c|}
\hline Genotypes & Controls & Patients & $\begin{array}{l}\text { Fisher's } \\
\text { P-value }\end{array}$ & $\begin{array}{l}\text { OR } \\
(\mathrm{CI})\end{array}$ & $\begin{array}{c}\text { Patients with } \\
\text { cancer stages } \\
\text { I \& II }\end{array}$ & $\begin{array}{l}\text { Fisher's } \\
\text { P-value }\end{array}$ & $\begin{array}{l}\text { OR } \\
(\mathrm{CI})\end{array}$ & $\begin{array}{c}\text { Patients with } \\
\text { cancer stages } \\
\text { III \& IV }\end{array}$ & $\begin{array}{l}\text { Fisher's } \\
\text { P-value }\end{array}$ & $\begin{array}{l}\text { OR } \\
(\mathrm{CI})\end{array}$ \\
\hline $\mathrm{C} / \mathrm{C}$ & $\begin{array}{c}0 \\
(0 \%)\end{array}$ & $\begin{array}{c}6 \\
(3.8 \%)\end{array}$ & $<0.001$ & $\begin{array}{c}40.88 \\
(2.24-744.40)\end{array}$ & $\begin{array}{c}4 \\
(4.5 \%)\end{array}$ & 0.0014 & $\begin{array}{c}78.12 \\
(3.97-1537.73)\end{array}$ & $\begin{array}{c}2 \\
(2.9 \%)\end{array}$ & 0.0273 & $\begin{array}{c}24.11 \\
(1.12-519.46\end{array}$ \\
\hline $\mathrm{G} / \mathrm{C}$ & $\begin{array}{c}9 \\
(5.4 \%)\end{array}$ & $\begin{array}{c}86 \\
(54.4 \%)\end{array}$ & $<0.001$ & $\begin{array}{c}21.31 \\
(9.82-46.21)\end{array}$ & $\begin{array}{c}48 \\
(54.5 \%)\end{array}$ & $<0.001$ & $\begin{array}{c}33.81 \\
(13.70-83.41)\end{array}$ & $\begin{array}{c}38 \\
(54.3 \%)\end{array}$ & $<0.001$ & $\begin{array}{c}15.36 \\
(6.50-36.31)\end{array}$ \\
\hline Total & $\begin{array}{c}168 \\
(100 \%)\end{array}$ & $\begin{array}{c}158 \\
(100 \%)\end{array}$ & & & $\begin{array}{c}88 \\
(100 \%)\end{array}$ & & & $\begin{array}{c}70 \\
(100 \%)\end{array}$ & & \\
\hline $\begin{array}{l}\text { Prevalence } \\
\text { of } \mathrm{C} \text { allele }\end{array}$ & & & & & & & & & & \\
\hline $\begin{array}{l}\mathrm{C} \text { allele } \\
\text { frequency }\end{array}$ & $2.7 \%$ & $31 \%$ & $<0.001$ & & $31.8 \%$ & $<0.001$ & & $30 \%$ & $<0.001$ & \\
\hline $\begin{array}{l}\text { Carrier } \\
\text { frequency } \\
\text { of } \mathrm{C} \text { allele }\end{array}$ & $5.4 \%$ & $58.2 \%$ & $<0.001$ & & $59.1 \%$ & $<0.001$ & & $57.1 \%$ & $<0.001$ & \\
\hline
\end{tabular}

All odds ratios are age-adjusted. TIMP-2, tissue inhibitor of metalloproteinase-2; CI, confidence interval.

history of thrombosis, iv) smoking habits and v) alcohol abuse (Tables II-IV). It should be mentioned though, that the very low number of non-smoking patients $(\mathrm{N}=10)$ does not allow safe conclusions to be drawn in this subgroup. On the contrary, the fact that the $\mathrm{C} / \mathrm{C}$ and $\mathrm{G} / \mathrm{C}$ genotypes were found to be significantly increased among the individuals with and without alcohol abuse implies that the effect of TIMP-2 is not influenced by alcohol during oral oncogenesis.

\section{Discussion}

Higher levels of activated MMPs have been implicated in tumor development and metastasis (25). An important mechanism for the down-regulation of MMPs is via binding to the tissue inhibitors of metalloproteinases (TIMP-1 through TIMP-4), which belong to a family of homologous proteins (26). TIMP-2 is not only a natural inhibitor of 
Table III. Prevalence of the TIMP-2 (-418G/C) polymorphism in the healthy controls and patients with oral cancer in regard to family history of either cancer or thrombosis.

\begin{tabular}{|c|c|c|c|c|c|c|c|c|c|c|c|c|c|}
\hline Genotypes & Controls & $\begin{array}{l}\text { Patients } \\
\text { with } \\
\text { family } \\
\text { history } \\
\text { of cancer }\end{array}$ & $\begin{array}{l}\text { Fisher's } \\
\text { P-value }\end{array}$ & $\begin{array}{l}\text { OR } \\
\text { (CI) }\end{array}$ & $\begin{array}{l}\text { Patients } \\
\text { without } \\
\text { family } \\
\text { history } \\
\text { of cancer }\end{array}$ & $\begin{array}{l}\text { Fisher's } \\
\text { P-value }\end{array}$ & $\begin{array}{l}\text { OR } \\
(\mathrm{CI})\end{array}$ & $\begin{array}{c}\text { Patients } \\
\text { with } \\
\text { family } \\
\text { history of } \\
\text { thrombosis }\end{array}$ & $\begin{array}{l}\text { Fisher's } \\
\text { P-value }\end{array}$ & $\begin{array}{l}\text { OR } \\
\text { (CI) }\end{array}$ & $\begin{array}{c}\text { Patients } \\
\text { without } \\
\text { family } \\
\text { history of } \\
\text { thrombosis }\end{array}$ & $\begin{array}{l}\text { Fisher's } \\
\text { P-value }\end{array}$ & $\begin{array}{l}\text { OR } \\
\text { (CI) }\end{array}$ \\
\hline \multirow[t]{2}{*}{$\mathrm{C} / \mathrm{C}$} & 0 & 4 & $<0.001$ & 78.12 & 2 & 0.0495 & 24.11 & 0 & $\mathrm{NC}$ & $\mathrm{NC}$ & 6 & $<0.001$ & 49.49 \\
\hline & $(0 \%)$ & $(6.9 \%)$ & & $(3.97-1537.73)$ & $(2 \%)$ & & $(1.12-519.46)$ & $(0 \%)$ & & & $(4.8 \%)$ & & $(2.71-904.76)$ \\
\hline \multirow[t]{2}{*}{$\mathrm{G} / \mathrm{G}$} & 159 & 22 & & 1 (referent) & 44 & & 1 (referent) & 16 & & 1 (referent) & 50 & & 1 (referent) \\
\hline & $(94.6 \%)$ & $(37.9 \%)$ & & & $(44 \%)$ & & & $(50 \%)$ & & & $(39.7 \%)$ & & \\
\hline \multirow[t]{2}{*}{$\mathrm{G} / \mathrm{C}$} & 9 & 32 & $<0.001$ & & & $<0.001$ & 19.33 & 16 & $<0.001$ & 27.54 & 70 & $<0.001$ & 19.85 \\
\hline & $(5.4 \%)$ & $(55.2 \%)$ & & $(10.50-66.69)$ & $(54 \%)$ & & $(8.38-44.59)$ & $(50 \%)$ & & $(9.19-82.56)$ & $(55.6 \%)$ & & $(8.91-44.24)$ \\
\hline \multirow[t]{2}{*}{ Total } & 168 & 58 & & & 100 & & & 32 & & & 126 & & \\
\hline & $(100 \%)$ & $(100 \%)$ & & & $(100 \%)$ & & & $(100 \%)$ & & & $(100 \%)$ & & \\
\hline \multicolumn{14}{|l|}{ Prevalence } \\
\hline \multicolumn{14}{|l|}{ of $\mathrm{C}$ allele } \\
\hline $\begin{array}{l}\mathrm{C} \text { allele } \\
\text { frequency }\end{array}$ & $2.7 \%$ & $34.5 \%$ & $<0.001$ & & $29 \%$ & $<0.001$ & & $25 \%$ & $<0.001$ & & $32.5 \%$ & $<0.001$ & \\
\hline $\begin{array}{l}\text { Carrier } \\
\text { frequency } \\
\text { of C allele }\end{array}$ & $5.4 \%$ & $62.1 \%$ & $<0.001$ & & $56 \%$ & $<0.001$ & & $50 \%$ & $<0.001$ & & $60.3 \%$ & $<0.001$ & \\
\hline
\end{tabular}

All odds ratios are age-adjusted. TIMP-2, tissue inhibitor of metalloproteinase-2; CI, confidence interval; NC, non calculable P-value.

Table IV. Prevalence of the TIMP-2 (-418G/C) polymorphism in the healthy controls and patients with oral cancer in regard to either alcohol consumption or smoking habits.

\begin{tabular}{|c|c|c|c|c|c|c|c|c|c|c|c|c|c|}
\hline Genotypes & Controls & $\begin{array}{l}\text { Patients } \\
\text { with } \\
\text { tobacco } \\
\text { abuse }\end{array}$ & $\begin{array}{l}\text { Fisher's } \\
\text { P-value }\end{array}$ & $\begin{array}{l}\text { OR } \\
\text { (CI) }\end{array}$ & $\begin{array}{l}\text { Patients } \\
\text { without } \\
\text { tobacco } \\
\text { abuse }\end{array}$ & $\begin{array}{l}\text { Fisher's } \\
\text { P-value }\end{array}$ & $\begin{array}{l}\text { OR } \\
\text { (CI) }\end{array}$ & $\begin{array}{l}\text { Patients } \\
\text { with } \\
\text { alcohol } \\
\text { abuse }\end{array}$ & $\begin{array}{l}\text { Fisher's } \\
\text { P-value }\end{array}$ & $\begin{array}{l}\text { OR } \\
\text { (CI) }\end{array}$ & $\begin{array}{l}\text { Patients } \\
\text { without } \\
\text { alcohol } \\
\text { abuse }\end{array}$ & $\begin{array}{l}\text { Fisher's } \\
\text { P-value }\end{array}$ & $\begin{array}{l}\text { OR } \\
\text { (CI) }\end{array}$ \\
\hline $\mathrm{C} / \mathrm{C}$ & $\begin{array}{c}0 \\
(0 \%)\end{array}$ & $\begin{array}{c}4 \\
(2.7 \%)\end{array}$ & 0.0069 & $\begin{array}{c}32.02 \\
(1.68-611.23)\end{array}$ & $\begin{array}{c}2 \\
(20 \%)\end{array}$ & 0.0011 & $\begin{array}{c}120.56 \\
(5.02-2897.22)\end{array}$ & $\begin{array}{c}2 \\
(3.8 \%)\end{array}$ & 0.0119 & $\begin{array}{c}63.82 \\
(2.83-1438.99)\end{array}$ & $\begin{array}{c}4 \\
(3.8 \%)\end{array}$ & 0.0034 & $\begin{array}{c}36.85 \\
(1.92-705.76)\end{array}$ \\
\hline $\mathrm{G} / \mathrm{G}$ & $\begin{array}{c}159 \\
(94.6 \%)\end{array}$ & $\begin{array}{c}62 \\
(41.9 \%)\end{array}$ & & 1 (referent) & $\begin{array}{c}4 \\
(40 \%)\end{array}$ & & 1 (referent) & $\begin{array}{c}18 \\
(34.6 \%)\end{array}$ & & 1 (referent) & $\begin{array}{c}48 \\
(45.3 \%)\end{array}$ & & 1 (referent) \\
\hline $\mathrm{G} / \mathrm{C}$ & $\begin{array}{c}9 \\
(5.4 \%)\end{array}$ & $\begin{array}{c}82 \\
(55.4 \%)\end{array}$ & $<0.001$ & $\begin{array}{c}23.40 \\
(10.69-51.21)\end{array}$ & $\begin{array}{c}4 \\
(40 \%)\end{array}$ & 0.0011 & $\begin{array}{c}11.27 \\
(1.53-83.14)\end{array}$ & $\begin{array}{c}32 \\
(61.5 \%)\end{array}$ & $<0.001$ & $\begin{array}{c}36.59 \\
(13.51-99.13)\end{array}$ & $\begin{array}{c}54 \\
(50.9 \%)\end{array}$ & $<0.001$ & $\begin{array}{c}17.34 \\
(7.65-39.31)\end{array}$ \\
\hline Total & $\begin{array}{c}168 \\
(100 \%)\end{array}$ & $\begin{array}{c}148 \\
(100 \%)\end{array}$ & & & $\begin{array}{c}10 \\
(100 \%)\end{array}$ & & & $\begin{array}{c}52 \\
(100 \%)\end{array}$ & & & $\begin{array}{c}106 \\
(100 \%)\end{array}$ & & \\
\hline $\begin{array}{l}\text { Prevalence } \\
\text { of } \mathrm{C} \text { allele }\end{array}$ & & & & & & & & & & & & & \\
\hline $\begin{array}{l}\mathrm{C} \text { allele } \\
\text { frequency }\end{array}$ & $2.7 \%$ & $30.4 \%$ & $<0.001$ & & $40 \%$ & $<0.001$ & & $34.6 \%$ & $<0.001$ & & $29.2 \%$ & $<0.001$ & \\
\hline $\begin{array}{l}\text { Carrier } \\
\text { frequency } \\
\text { of } \mathrm{C} \text { allele }\end{array}$ & $5.4 \%$ & $58.1 \%$ & $<0.001$ & & $60 \%$ & $<0.001$ & & $65.4 \%$ & $<0.001$ & & $54.7 \%$ & $<0.001$ & \\
\hline
\end{tabular}

All odds ratios are age-adjusted. TIMP-2, tissue inhibitor of metalloproteinase-2; CI, confidence interval. 
MMP-2 but a suppressor of endothelial cell proliferation and angiogenesis as well $(10,11)$. The complexity of the TIMP-2 functions indicates a possibly multiple role in cancer progression and metastasis $(13,14,27)$. The levels of TIMP-2 have been correlated with the progression of OSCC, in addition to other carcinomas (12,14-16,27).

A single nucleotide polymorphism $(-418 \mathrm{G} / \mathrm{C})$ in the promoter region of the TIMP-2 gene affects its transcription (20). Gene expression is lower when the less common C allele is present $(18,20)$. In this light, the purpose of this study was to investigate the possible role of the $-418 \mathrm{G} / \mathrm{C}$ polymorphism in the risk of developing oral oncogenesis by comparing the TIMP-2 genotypes of patients with oral cancer and healthy controls of equivalent age, sex and ethnicity.

Despite the relatively small number of studied individuals, the overall obtained data revealed a strong association of the low expression $\mathrm{C}$ allele with an increased risk of developing oral cancer $(\mathrm{P}<0.001)$. Both the homozygous state $\mathrm{C} / \mathrm{C}$ as well as the heterozygous $\mathrm{G} / \mathrm{C}$ genotype were strongly associated with an increased risk of developing oral oncogenesis $(\mathrm{P}<0.001)$, indicating that the low expression $\mathrm{C}$ allele acts as a dominant genetic character. The association of the TIMP-2 polymorphism with oral cancer was so strong that no additive effect of the environmental factors that are known to be tumorigenic in the oral cavity (such as tobacco and alcohol) was observed.

These findings could be explained by the reduced amount of TIMP-2 in the presence of the $\mathrm{C}$ allele, which is insufficient to inhibit MMP-2 and mitogen-driven angiogenesis $(10,11,20)$. MMP-2 is a protease involved in the degradation of the extracellular matrix and thus contributes to cancer invasion and metastasis, while neoangiogenesis is important for the viability, growth and metastastic potential of tumors $(10,11,25)$.

The present study is not in accordance with another study conducted in a Thai population, concerning head and neck cancer (20). The distribution of the genotypes concerning the $-418 \mathrm{C} / \mathrm{G}$ polymorphism in Thais was only borderline different $(\mathrm{P}=0.059)$ between the patients and the controls, while no significant difference was found among the $\mathrm{C}$ allele frequencies between the patients and the controls $(\mathrm{P}=0.320)$ (20). Nevertheless, only $46.4 \%$ of the Thai patients had OSCC (20). Therefore these results are not fully comparable with the findings of the present study. Diverse tumorigenic mechanisms possibly exist among tumors of the oral cavity and neck. This notion is reinforced by a number of studies, in which the polymorphisms in the MMP-1 or IL- 8 genes have been associated with oral cancer but not esophageal cancer $(9,28-30)$. Moreover, this discrepancy could be due to the fact that the frequency of the $\mathrm{C}$ allele is more common in the Thai controls (17.2\%) and rare in Europeans (only 2.7\%), indicating that there are differences in the distribution of genotypes among these ethnicities.

In conclusion, the studied TIMP-2 polymorphism is strongly associated with an increased risk of OSCC in Europeans carrying the low expression $\mathrm{C}$ allele. These results indicate that this polymorphism could serve as a genetic marker for the susceptibility to cancer in the oral cavity. Since other factors related to angiogenesis, inflammation and thrombosis have been also associated with this malignancy
(7-9), further studies are necessary in order to clarify the role of all the potential genetic and environmental factors in the formation of OSCC, in an effort to safeguard the health status and lives of certain individuals who are at risk in the general population.

\section{Acknowledgements}

This study was co-funded by the European Social Fund and National Resources (EPEAEK II 'Pythagoras' 70/3/7391) grant to E.V.

\section{References}

1. Das BR and Nagpal JK: Understanding the biology of oral cancer. Med Sci Monit 8: 258-267, 2002.

2. Sudbo J: Novel management of oral cancer: a paradigm of predictive oncology. Clin Med Res 2: 233-242, 2004.

3. Williams HK: Molecular pathogenesis of oral carcinoma. J Clin Pathol 53: 165-172, 2000.

4. Song C, Xing D, Tan W, Wei Q and Lin D: Methylenetetrahydrofolate reductase polymorphisms increase risk of esophageal squamous cell carcinoma in a Chinese population. Cancer Res 61: 3272-3275, 2001.

5. Vairaktaris E, Yapijakis C, Wiltfang J, et al: Are factor V and prothrombin mutations associated with increased risk of oral cancer? Anticancer Res 25: 2561-2566, 2005.

6. Vairaktaris E, Yapijakis C, Kessler P, et al: Methylenetetrahydrofolate reductase polymorphism and minor increase of risk for oral cancer. J Cancer Res Clin Oncol 132: 219-222, 2006.

7. Vairaktaris E, Yapijakis C, Serefoglou Z, et al: Plasminogen activator inhibitor-1 polymorphism is associated with increased risk for oral cancer. Oral Oncol 42: 888-892, 2006.

8. Vairaktaris E, Yapijakis C, Derka S, et al: Association of platelet glycoprotein Ia polymorphism with minor increase of risk for oral cancer. Eur J Surg Oncol 32: 455-457, 2006.

9. Vairaktaris E, Yapijakis C, Serefoglou Z, et al: The interleukin$8(-251 \mathrm{~A} / \mathrm{T})$ polymorphism is associated with increased risk for oral squamous cell carcinoma. Eur J Surg Oncol (in press).

10. Seo DW, Li H, Guedez L, Wingfield PT, et al: TIMP-2 mediated inhibition of angiogenesis: an MMP-independent mechanism. Cell 114: 171-180, 2003.

11. Fernandez CA, Butterfield C, Jackson G and Moses MA: Structural and functional uncoupling of the enzymatic and angiogenic inhibitory activities of tissue inhibitor of metalloproteinase-2 (TIMP-2): loop 6 is a novel angiogenesis inhibitor. J Biol Chem 278: 40989-40995, 2003.

12. Gao ZB, Duan YQ, Zhang L, Chen DW and Ding PT: Expression of matrix metalloproteinase 2 and its tissue inhibitor in oral squamous cell carcinoma. Int J Mol Med 16: 599-603, 2005.

13. Hayakawa T, Yamashita K, Ohuchi E and Shinagawa A: Cell growth-promoting activity of tissue inhibitor of metalloproteinases-2 (TIMP-2). J Cell Sci 107: 2373-2379, 1994.

14. Gakiopoulou H, Nakopoulou L, Siatelis A, et al: Tissue inhibitor of metalloproteinase- 2 as a multifunctional molecule of which the expression is associated with adverse prognosis of patients with urothelial bladder carcinomas. Clin Cancer Res 9: 5573-5581, 2003.

15. Ruokolainen H, Paakko P and Turpeenniemi-Hujanen T: Tissue and circulating immunoreactive protein for MMP-2 and TIMP-2 in head and neck squamous cell carcinoma - tissue immunoreactivity predicts aggressive clinical course. Mod Pathol 19: 208-217, 2006.

16. Kim TJ, Rho SB, Choi YL, et al: High expression of tissue inhibitor of metalloproteinase-2 in serous ovarian carcinomas and the role of this expression in ovarian tumorigenesis. Hum Pathol 37: 906-913, 2006.

17. DeClerck YA, Darville MI, Eeckhout Y and Rousseau GG: Characterization of the promoter of the gene encoding human tissue inhibitor of metalloproteinase-2 (TIMP-2). Gene 139: 185-191, 1994.

18. Hirano K, Sakamoto T, Uchida Y, et al: Tissue inhibitor of metalloproteinase-2 gene polymorphisms in chronic obstructive pulmonary disease. Eur Respir J 18: 748-752, 2001.

19. Faisst S and Meyer S: Compilation of vertebrate-encoded transcription factors. Nucleic Acids Res 20: 3-26, 1992. 
20. O-charoenrat $\mathrm{P}$ and Khantapura $\mathrm{P}$ : The role of genetic polymorphisms in the promoters of the matrix metalloproteinase-2 and tissue inhibitor of metalloproteinase- 2 genes in head and neck cancer. Oral Oncology 42: 257-267, 2006.

21. Yifeng Z, Chunyuan Y, Xiaoping M, et al: Substantial reduction in risk of breast cancer associated with genetic polymorphisms in the promoters of the matrix metalloproteinase- 2 and tissue inhibitor of metalloproteinase-2 genes. Carcinogenesis 25: 399-404, 2004

22. De Souza AP, Trevilatto PC, Scarel-Caminaga RM, et al: Analysis of the MMP-9 (C-1562 T) and TIMP-2 (G-418C) gene promoter polymorphisms in patients with chronic periodontitis. J Clin Periodontol 32: 207-211, 2005.

23. Peres RCR and Line SRP: Analysis of MMP-9 and TIMP-2 gene promoter polymorphisms in individuals with hypodontia. Braz Dent J 16: 231-236, 2005.

24. Hegab AE, Sakamoto T, Uchida Y, et al: Association analysis of tissue inhibitor of metalloproteinase 2 gene polymorphisms with COPD in Egyptians. Respir Med 99: 107-110, 2005.

25. Katayama A, Bandoh N, Kishibe K, et al: Expressions of matrix metalloproteinases in early-stage oral squamous cell carcinoma as predictive indicators for tumor metastases and prognosis. Clin Cancer Res 10: 634-640, 2004.
26. Brew K, Dinakarpandian D and Nagase H: Tissue inhibitors of metalloproteinases: evolution, structure and function. Biochim Biophys Acta 1477: 267-283, 2000.

27. Remacle A, McCarthy K, Noel A, et al: High levels of TIMP-2 correlate with adverse prognosis in breast cancer. Int J Cancer 89: 118-121, 2000.

28. Savage SA, Abnet CC, Mark SD, et al: Variants of the IL8 and IL8RB genes and risk for gastric cardia adenocarcinoma and esophageal squamous cell carcinoma. Cancer Epidemiol Biomarkers Prev 13: 2251-2257, 2004.

29. Jin X, Kuang G, Wei LZ, Li Y, et al: No association of the matrix metalloproteinase 1 promoter polymorphism with susceptibility to esophageal squamous cell carcinoma and gastric cardiac adenocarcinoma in northern China. World J Gastroenterol 11: 2385-2389, 2005.

30. Cao ZG and Li CZ: A single nucleotide polymorphism in the matrix metalloproteinase-1 promoter enhances oral squamous cell carcinoma susceptibility in a Chinese population. Oral Oncol 42: 32-38, 2006 